\title{
BRADLEY MONTON
}

\section{University of Colorado}

\section{Evan Fales. Divine Intervention: Metaphysical and Epistemological Puzzles. Routledge, 2010.}

How does God do things? What can God know? Do we have experience of God? These are the three questions that motivate Evan Fales's sometimes frustrating, sometimes fascinating book, Divine Intervention: Metaphysical and Epistemological Puzzles.

Fales isn't clear on whether or not he believes in God. Superficially, it sometimes sounds like he does, when for example he asks questions like: 'How exactly does God make things happen in our world?' (p. 3) But other times, it seems like he doesn't, when for example he presents a problem regarding God's omniscience, and says that 'the theist' does not have 'an easy escape' (p. 70).

There's a sense in which Fales's secrecy regarding his own beliefs is fine: atheists and theists can discuss the philosophical issues equally well; one doesn't need to put one's cards on the table before doing philosophy of religion. But the problem is that it's sometimes hard to figure out where Fales is going with his discussion - he often raises worries, says that the discussion is inconclusive, and then moves on. Perhaps that's all he's trying to do, but one gets the sense that there's more going on. Specifically (both from reading this book and reading Fales's other work), I gather that he's more on the atheist side of the atheist/theist spectrum, and he's trying to raise worries for theistic belief. (This comes out most clearly toward the end of the book, as I'll discuss below.)

While Fales doesn't quite present his book this way, I see it as divided into three parts. The first part discusses metaphysical issues, involving how God could interact with the world. The second part involves epistemological issues, such as whether God could be omniscient, and whether God faces sceptical worries. The third part critiques the argument from religious experience for the existence of God. I'll discuss each of these parts below. Some foreshadowing: the metaphysics part is sometimes frustratingly inconclusive and sometimes interesting, the religious experience part doesn't have much new, and the epistemology part is exciting and thought-provoking.

First, metaphysics. Is it even possible for a nonphysical being like God to interact with the physical world, and if so, how does God do it? 
Fales discusses various views of the nature of causation, to try to figure this out, but concludes:

We know as yet too little about causation, as I judge, to come to reasonably definitive conclusions about the nature, or even the possibility, of divine interventions in the physical order. (p. 154)

He also takes up the question of whether God establishes what the laws of nature are, and the question of whether the laws, once established, could be suspended. His conclusion is similarly inconclusive:

We do not have firm enough a grasp upon laws, and perhaps also on space and time, to arrive at clear determinations of the possibilities here. (p. 154)

Fales's positive contribution here is 'to bring into relief the inadequacy of the fiat lux model of divine activity, which has too commonly been taken to settle the matter' (p. 36). According to the fiat lux model, God creates just by commanding. But Fales rightly asks a question: 'what is the connection between God so commanding, and its coming to pass?' (p. 33) It appears that this connection is a causation relation, and needs a corresponding law of nature governing this causal relation. But where does that law of nature come from? It's hard to see how this law of nature could come from God's command, on pain of vicious regress.

The other issue in metaphysics Fales discusses is the relationship between God and time. Here the discussion is less inconclusive, but I'm not happy with Fales's conclusion. He writes:

If there were a universe lacking a preferred reference frame [and our universe is such a universe, according to the standard interpretation of Einstein's theory of relativity], there would be no facts of the matter of how God relates temporally to that universe - when He acts in that universe, which of His actions are simultaneous, or what the temporal relationship is between His willing that a certain event occur in that universe, and the time of its occurrence. (p. 56)

Well, in a universe with no preferred reference frame, the standard view is that the eternalist theory of time is true. According to eternalism, the universe is a four-dimensional space-time system, with no objective facts about which events are past, present, or future, and no objective flow of time. In such a universe, there are no objective facts about simultaneity for events that are located in different regions of the universe - but it is reasonable to hold that events that are co-located are simultaneous. My 
view is that, in an eternalist universe, we need to take God's omnipresence seriously - when God acts in the universe, he is co-located with the physical region of spacetime that contains the effect of his act. Since God sustains the universe in existence, God is co-located everywhere, and God's actions are simultaneous with the effects of God's actions. Pace Fales, I don't see a problem here.

Let's turn to the third part of Fales's book, saving the most exciting second part for last. In the third part, Fales critiques the argument from religious experience for the existence of God. Specifically, Fales argues that there are no adequate criteria distinguishing veridical mystical experiences from illusory ones. He also argues that the account of mystical experiences that maintains that they are somehow caused by God is a less satisfactory account than that which holds that they can be accounted for naturalistically, via the resources of anthropology and neurophysiology. Fales concludes that mystical experiences do not provide anyone with good evidence for supernatural reality.

Fales is savvy enough to recognize that simply providing a naturalistic explanation for mystical experiences isn't enough to disqualify mystical experiences as evidence of the supernatural - it could be that the naturalistic explanation correctly says, for example, that the mystical experiencer is in a certain brain state, while there is also a correct supernatural explanation of why the experiencer is in that brain state. But Fales goes on to argue that, for the case of mystical experiences, the anthropological and neurophysiological explanations are better than just the supernatural one, and attempting to add a supernatural explanation to the anthropological and neurophysiological explanations diminishes the force of the naturalistic explanations.

Overall, I didn't find that much philosophically new in Fales's critique of the argument from religious experience. The most interesting parts were his appeals to anthropology and neurophysiology. On the anthropology side, Fales discusses the work of I. M. Lewis, who argues that certain social contexts are more likely to produce people who act as mystics, and claim to have mystical experiences. On the neurophysiological side, Fales points out that certain types of mystical experiences can be generated by electrical stimulation of parts of the brain. He puts forth the interesting hypothesis that people who are more prone to having religious experience have thinner myelin sheathing on their nerves in the temporal lobe, so that electrical signals can jump from one axon to neighbouring ones, thus releasing an avalanche of nerve firings that give 
rise to the feeling of a mystical experience. Fales maintains that such naturalistic accounts cannot be happily supplemented with an appeal to God as the cause of mystical experiences.

Let's turn, finally, to the second and most exciting part of Fales's book, his discussion of epistemological issues. Fales gives two arguments for the view that God is not omniscient. His first argument holds that God is 'impassible', and hence that God can't know the contingent facts that could only be known by perceiving the world. Fales doesn't define 'impassible', and while it often means 'incapable of suffering or feeling pain', I take from context that Fales means something stronger. He writes:

God, it is generally supposed, is impassible. And that means that no created object is causally responsible for anything that happens to God: nothing ever happens to God. (p. 71)

Fales argues that, because God is impassible, God can't perceive the world, and hence can't know contingent facts about the world. This is, clearly, a result that traditional theists would not be at all happy with. How would they respond?

One response Fales considers is for the theist to hold that God knows everything about the world because God knowingly wills it, and God knows that what God wills is fulfilled (p. 72). But Fales points out two interesting difficulties for this response. One difficulty is: how does God know that God's will is successful? God can't know it by way of empirical investigation, under the assumption that God is impassible (in Fales's strong sense that God is not causally affected by the world). Perhaps God could know that there is a law-like connection between his will and the effects of his will via a priori means. But Fales says that it is not easy to see ... how a law is the sort of thing that could be known a priori (even by God)' (pp. 72-3).

The second difficulty Fales raises for the response that God knows everything about the world because God knowingly wills it is that (according to Fales) God does not will everything that happens in the world - if something like the standard interpretation of quantum mechanics is true, then fundamental physical processes are indeterministic. Fales doesn't go into this in detail, but I think this raises an interesting concern about God's control over what happens in the world. For example, according to quantum mechanics, there's a non-zero chance that we could all die in the next second, if for example enough of our particles scatter to distant regions (which is allowed by quantum 
mechanics, since the wave function tails for a particle extend to infinity). Presumably God is not simply leaving it up to chance that we continue to exist; this makes me think that God is at least willing to exert his will over even indeterministic events in the universe.

All this is in response to Fales's argument that God is not omniscient because he's impassible. I think that the most promising way to respond to Fales's argument is simply to hold that God is impassible only in the sense that he doesn't suffer, not in the sense that he's not causally affected by the world. Fales recognizes this option, and his counterreply is simply to move on to his second argument for the claim that God is not omniscient.

Fales's second argument for the claim that God is not omniscient applies the argument of an epistemological sceptic to God himself. Specifically, Fales asks, how does God know that he is not being deceived by an evil demon? Fales's discussion here is sophisticated and intriguing, and I won't be able to do it justice. Fales's overall point is that 'God Himself has no reasoned response to the sceptical worry that His cognitive faculties might be in some way defective' (p. 83). God can't know that they aren't defective through his own activity - even if he decided to banish epistemological evil demons from the world, how could be he be certain that he had successfully done so? Fales says that, for God to be omniscient, 'God must just set aside the conceptual possibility raised by the sceptic' (p. 84). But in doing so, God isn't being perfectly rational. Fales concludes that God can be either omniscient or perfectly rational, but not both.

At the end of his book, Fales correctly points out that he has avoided talking about the traditional, familiar puzzles associated with God's omnipotence and omniscience. This is true, but as a result the philosophy in Fales's book sometimes seems comparatively underdeveloped. But Fales is to commended for raising new issues, and trying to start new debates. Given the long history of philosophy of religion, this is hard to do, and Fales deserves credit for being successful in doing so. 